\title{
The Impact of "Offer for Sale" by Existing Shareholders in an IPO on Initial Aftermarket Performance
}

\author{
Norliza Che-Yahya \\ Faculty of Business and Management \\ Universiti Teknologi MARA, Puncak Alam Campus, Malaysia \\ E-mail: norliza9911@puncakalam.uitm.edu.my
}

\author{
Ahmad Husni Mohd Rashid \\ Faculty of Business and Management \\ Universiti Teknologi MARA, Puncak Alam Campus, Malaysia \\ E-mail: ahmadhusni@salam.uitm.edu.my
}

Ibrahim A. Rahman

Faculty of Business and Management

Universiti Teknologi MARA, Puncak Alam Campus, Malaysia

E-mail: ibrahim014@salam.uitm.edu.my

Siti Norbaya Mohd Rashid

Faculty of Business and Management

Universiti Teknologi MARA, Puncak Alam Campus, Malaysia

E-mail: norbaya@uitm.edu.my

Received: July 12, 2017 Accepted: October 11, $2017 \quad$ Published: December 1, 2017

doi:10.5296/ajfa.v9i2.11537 URL: https://doi.org/10.5296/ajfa.v9i2.11537 


\section{Abstract}

This study examines the impact of "offer for sale" by existing shareholders in an IPO on initial aftermarket performance. The "offer for sale" is measured by the proportion of shares offered to public from the sale of the existing shareholdings against the total number of shares offered during IPO. The "offer for sale" activity suggests that proceed from the shares sold to investors at an IPO would go into the pocket of the existing shareholders. That is, the proceed does not actually meet the goals of the IPO which is to raise fund. The new investors expect new cash inflows for the firm to finance new projects and to secure its sustainable growth. IPO firms that go public mainly through "offer for sale" activity are expected to receive less demand during the IPO from the potential investors. In other words, the investors prefer to invest more in IPO firms that offer entirely newly issued shares rather than those that offer a combination of "public issue" and "offer for sale". Firms which their shares are offered through "offer for sale" activity are predicted to produce poor initial aftermarket performance relative to firms which their shares are newly issued. Employing a sample of 419 Malaysian IPOs issued from January 2000 to December 2015, regression results of this study reveal that firms which their shares are offered highly through "offer for sale" report poor initial aftermarket performance.

Keywords: Offer for sale, Initial Aftermarket Performance, Malaysian IPO Market 


\section{Introduction}

Malaysian economic performance has shown tremendous growth since Malaysia become independence in 1957. At an average of GDP $6 \%$ growth per year from 1970s to 2005, the economy sustained rapid growth of $8 \%$ annually. The creation of funds is needed to support the growth, and Malaysia is so accustomed to build the economy and trade from the flow of capitals across the globe. Private sector activity remained the key driver of growth expanding at a very fast pace. Private investment grew mainly driven by continuous capital spending especially in the services and manufacturing sector. As private sector continues to grow, companies will be focusing on need to raise funds in order to complement the government and businesses.

Most business fails because they lack the cash to get through the early stages of their existences. Capital is crucial at the start of the company life as it enables the business to turn ideas to reality. The seed capital may be used to hire key staff, purchase inventory or market the company and its ideas. All these require cash and for these the reasons companies raise investment strategizing the future growth chart for the companies. The question that will be raised is, what the companies sell that attracted investors to lend money to the company?

Raising funds through IPOs is a very popular ways to raise funds for a company. IPOs is where a private company going public by selling its share to the public in an initial public offering. The public offerings will be done thru an investment bank appointed by the company. It will go through a complex process in trying to determine the marketability and saleability of the shares offered. The advantages of issuing IPOs is that the company may grow its business without taking any debt financing that will avoid the company from paying interest and required to service interest payment. With the money on the coffer from the selling of stock, company will also be able to give better compensation to their manager, owner and founder of the company. Once it become a public company, additional business will be made easier and especially if the company become more successful.

What will companies' sell that will attract the investor to purchase the shares. Companies finance their investment opportunities in the form of real assets, inventory and capital expenses. The proceed of the IPOs will provide cash flow for the companies that can be used to finance new positive NPV projects that can be lead to further growth for the company (Garfinkel,1993). This can be translated into the appreciation of shares in the futures. However, companies sometimes can exploit investors' lack of knowledge towards the market by overvaluing their shares, hoping that they will get more cash flow. However, studies have shown that overvalued shares will experience poor long run performance (Kavita Wadhwa, V. Naggi Reddy, Abhinav Gopal, Abdulkadir Mohamed, 2016).

Investor chooses initial Public Offering for many reasons. Besides having good multiples, evaluating through the prospectus, will allow investor to analyse the IPO stock more meticulously and thoroughly as to compare with buying stock under secondary market. The price that is being offered and the funds collected indeed reflect the performance and expected future growth of the companies. The expectation of investor is always that the cash flow from the IPO is to be plough back to the company so that they will be used it to create 
growth. However some IPOs do not offer entirely new shares but also a proportion of it comes from the shares of the existing shareholders.

What if the total IPO raised is not being used for the future growth of the company? IPOs that are issued and raised together with the "offer for sale" as part of the IPO but the offer for sale would be used to distribute cash to the existing shareholders. What would the perception of the investors in this type of IPO? Would they perceive that shareholders have lack of confidence to the future plan of the company or the price offered is above their valuation price. Would the negative perception to the selling of IPO shares, lower the demand of the IPO shares price in the initial aftermarket performances. Can it have an influence on the price aftermarket performance? We would like to do a research on the premises that the portion of the IPOs goes back to the shareholders will carry an impact to the IPOs sales.

The remaining sections of this paper is organized as follows; Section 2 reviews relevant literature. Section 3 describes the data and methodology used in this study. Section 4 presents and discusses the empirical results while Section 5 concludes the findings.

\section{Literature Review}

\section{IPO Initial Aftermarket Performance Worldwide}

A lot of investors loves a good IPO story, whether it's a company that soared after its initial offering or one that have overinflated in the early excitement. Mayur \& Kumar (2013) founds that Indian firm who go public want to raise capital for their growth and expansion, diversify the risk of initial owners and capital structure rebalancing, bring down their cost of capital, increase the liquidity of their shares, avoid excessive monitoring or large shareholders and to seek publicity. Younger, riskier, transparent, more profitable, experiencing higher sales growth and size of the company will become larger are the impact to those companies who go public. However, there are cost in becoming public which are information asymmetry and adverse selection cost, experience loss of confidentiality, and bear initial and subsequent expenses.

Investors are actively into flipping activity which continue until subsequent week in the Malaysia IPO market. Stock market regulator need to do something since extreme flipping activity might detrimental the secondary IPO market. Abdul Rahim, Sapian, Yong, \& Auzairy (2013) found that extreme flipping activity will create synthetic pressure on the IPO price that garb for speculative activities. While study done by Islam, M. S., \& Munira S. (2004) found that IPO flipping is certain in the initial aftermarket. Bangladesh market is stimulus by institutional investors and issue size. It helps investor in predicting the liquidity and price of IPO stock in the immediate aftermarket. As to limit the proportion of institutional investor preferable to do flipping activity, SEC as regulatory authority may consider to convincing the issuer to allocate lower proportion of new issues.

Mohd Rashid, Abdul Rahim, Hadori, \& Tanha (2013) examines the variability in initial return, IPO volumes, and market conditions of the IPO listed in Bursa Malaysia during the period from January 2000 to December 2010. Initial return and market condition may give a signal of the IPO volume as it also influence the decison of the company to go public. IPOs 
are risky in the long run and also for the first few weeks after the listing. Besides initial return and market condition, companies also study on market volatility before they make decision to go public as it has positive relationship with IPO volume.

Studied done by Sahoo \& Rajib (2010) on 92 Indian IPOs issued during the period of 2002 to 2006, it shows that Indian IPOs are underpriced on the listing day as compared to market index besides during the initial year of trading but may gain positive market-adjusted return thereafter. Underperformance of the IPOs are due to initial day return, offer size, leverage at IPO date, ex-ante uncertantity and timing of issue. Traditionally, Jegadeesh, Weinstein \& Welch (1993) found that IPO underpricing and the probability and size of subsequent seasoned offerings has a positive relationship. Those firms are likely to issue seasoned equity within three years of their IPOs in a large amount when they experience relatively larger IPO-date returns.

Abdul Rahim et. al (2012) studied the winner's curse hypothesis in a sample of 384 IPOs listed on Bursa Malaysia from 1999 to 2008. When the IPOs are overpriced, investors are more likely to gain more in their subscription. Investors are advisable to gather all available information that may influence the IPOs performance before making decision to subscribe any IPOs. Besides that, during the participation of institutional investors in the IPOs, uninformed investors are willingly to pay high offer price and accept lower initial returns since they are confidence on the performance of the IPOs. But, to make the non-private placement IPOs are fully subscribed, uninformed investors need to be persuade with larger initial returns during the absence of informed investors.

\section{Offer for sale and Hypothesis}

A longer lockup period may give a signal to venture capital (VC) and the reputation of underwriter backing (J.D. Arthurs et al., 2009). Underpricing can be avoided when the lockup period is longer. However, during a longer lockup period, managers with sizeable ownership may resort to risky decisions since they afraid a certain loss of wealth. But, managers may become risk averse and avoid making risky decisions during shorter lockup period.

Mohd Rashid, Abdul-Rahim, \& Yong (2014) examines the issue of lock-up provisions (ratio and period) in IPOs and their relationship with initial returns using a dataset from Bursa Malaysia spanning the period from January. examines whether the lock-up ratio and lock-up period affect the initial returns, using a sample of 384 IPOs listed on Bursa Malaysia between 2000 and 2012. The results of the cross-sectional multiple regression show that the lock-up period is significantly positive in explaining IPO initial returns, but the lock-up ratio is not. The findings provide new insights for testing the signaling content of lock-up provisions, particularly in a setting characterized by high information asymmetry, lock-up ratios and lock-up periods are predicted to have a positive influence on the initial returns of IPOs based on the risk-signaling hypothesis.

Study on moderating effect of information asymmetry on the relationship between parameters of lockup provision and flipping activity of Malaysian IPOs has been done by Abdul-Rahim $\&$ Che Yahya (2015). Lock-up provision is to promote committment among the major 
shareholders as not to sell their shares after the process of the IPO but also it provide signal on the initial return. This study founds that the lockup provision has a greater influence on flipping activity in higher than lower information asymmetry companies. Both lockup ratio and lockup period have significantly negative impacts on flipping activities. The results imply that investors have a greater tendency to flip during the post-2008 revision period when major shareholders are perceived to be less strongly accounted for their firms ${ }^{\text {ee }}$ performance. The results also show that information asymmetry moderates the negative relationship between lockup provision and flipping activity, specifically, in regards to lockup period.

\section{Research Methodology}

\section{Sample Size and Procedures}

The population of this study is all IPOs listed on Bursa Malaysia from January 2000 to December 2015. There were 540 IPOs listed during this period. The final sample of this study consists of 419 IPOs, which is 77.59 per cent of the total population. This study starts the sample period in 2000 to reduce the noise from the 1997/98 Asian financial crisis on the analysis. The sample period ends in 2015 as that is the latest coverage year the analysis could achieve as some information (e.g., proportion of lock-up shares) need to be validated with information provided by IPO issuer in its first annual report a year after the listing. All rare type IPOs (i.e., Restricted offer for sale, restricted public issue, restricted for sale to eligible employees, special and restricted issue to Bumiputra investors, tender offer and special issue) and IPOs with missing value were omitted. Similarly, IPOs issued by financial and insurance firms due to differences in the regulatory structure of the industry (Schaub et al., 2003). Data for this study were sourced from prospectuses of the IPO issuers, the website of Bursa Malaysia and the database of DataStream.

\section{Variables Definition and Analytical Methods}

\section{Initial Return}

The independent variable of this study, initial return (RETURN), is measured as the percentage change in price, between the closing price on the first day of trading and the offer price. To reduce market interference and noise on the return of a stock, this study re-measure initial return using the percentage change in opening price on the first day of trading and the offer price (Mohd Rashid et al., 2014; 2016; Yong, 2010). As suggested in Yong (2010). the opening price is more able to capture the first reaction of investors upon the listing of an IPO. The measure is shown as follows:

$$
\begin{aligned}
& \operatorname{RETURN}_{\text {OPEN }^{i}}=\left(\frac{\text { POPEN } i_{i} \text { POFFER }_{i}}{\text { OFFER }_{i}}\right) x 100 \\
& \text { RETURN }_{\text {CLOSE }} i=\left(\frac{\text { PCLO } i-P_{\text {OFFER }_{i}}}{\text { POFFER }_{i}}\right) x 100
\end{aligned}
$$


where,

$$
\begin{aligned}
& P_{\text {OPENi }}=\text { opening price on the first trading day for the } i \text { th issuer, } \\
& P_{C L O i}=\text { closing price on the first trading day for the } i \text { th issuer, and } \\
& P_{\text {OFFER } i}=\text { offer price for the } i \text { th issuer. }
\end{aligned}
$$

\section{Offer for Sale}

The main independent variable of this study, offer for sale (OFSALE), is defined as the selling down one or more shareholdings of a firm by existing shareholders during IPO (Espinasse, 2011) and is measured by the ratio of total number of shares offered or sold by existing shareholders to total shares offered in an IPO (Bildic \& Yilmaz, 2008). The measure is shown as follows:

$$
\mathrm{OFSALE}_{i}=\mathrm{NOFSA}_{i} / \mathrm{NOSHI}_{i}
$$

where,

$$
\begin{aligned}
& \text {NOFSA }_{i}=\text { offer for sale of the } i \text { th issuer, and } \\
& \text {NOSHI }_{i}=\text { total number of shares offered for the } i \text { th issuer. }
\end{aligned}
$$

\section{Control Variables}

The control variables of this study comprises of demand of IPO (DEMAND) which is measured by subscription ratio. The initial return is expected to be significantly positively related to RETURN because investors perceive that the highly demanded IPOs indicate the value of the shares at the early listing days as well as the quality of the issuing firms (Abdul Rahim et al., 2013; Islam \& Munira 2004). Accordingly, investors are more likely join the pool to subscribe for the shares. The demand-supply theory would suggest that the higher demand will result in higher IPO price. Next, supply of IPO (SUPPLY) is measured as the natural $\log$ of the total number of shares offered for an IPO multiplied by its offer price (LN (NOSHI x $\left.P_{\text {OFFERi }}\right)$ ) (Bayley, Lee, \& Walter, 2006; Chong, Ali, \& Ahmad, 2009). Larger offer size indicates a larger supply of the IPO that ceteris paribus, more subscription applications will be fulfilled during allotment stage and less will be demanded during the first few trading days (Sapian, Abdul Rahim, \& Yong, 2012). This argument leads to the expectation that larger issue will result in lower initial return.

Market condition (MKT) signifies the overall performance of the stock market. Market condition is measured by the average one week returns of FTSE Bursa Malaysia Emas index. A positive pre- average market return suggests that the investors are optimistic and confident about the present market outlook which in turn affects positively on their attitude toward initial return of the new issues (Chong et al., 2009; Ritter \& Welch, 2002). Therefore, a 
positive relationship between MKT and RETUTN is expected. Next control variable of this study, investors' sentiment reflected by heurestic representative, is measured by the average returns on the opening trading day of the three most recent new issues listed prior to an IPO. Unlike the overall stock market condition (MKT), heuristic representative signifies the investor sentiment in a smaller scope i.e., how investors evaluate an IPO (winner or loser) and/or a market (bull or bear) based on what has happened in the most recent period. Positive (negative) mean initial returns of the three most recently issued IPOs tend to elicit optimistic (pessimistic) sentiment among the investors (Bayley et al., 2006; Chong et al., 2011). Similarly, this suggests that the optimism among market players, which allows for higher prices (or initial return).

Underwriters' reputation (UNDREP) usually reflects the credibility of investment banks in pricing, selling and certifying an IPO. A credible investment bank is supposed to have the experiences and expertise that are necessary to estimate the true value and quality of the issuing company. Therefore, the use of a reputable underwriter is expected to reduce the severity of information asymmetry between the insiders and the outside investors (Yung \& Zender 2010) such that increase the confidence of investors in investing in some firms. With that concept in mind, this study expect a positive relationship between UNDREP and initial return. This study measures the underwriter reputation using its market shares on a particular year. Specifically, the market shares of underwriter is percentage of the total amount of shares underwritten by the underwriter against the total amount of shares underwritten by all underwriters in the specific listing year. As suggested by Fang (2005), the market share is a preferable indicator as it naturally reflects the 'brand name' and the 'goodwill' of an underwriter.

Institutional investors are perceived to be informationally opaque that they should only invest in companies with good prospects of future cash flows (Aggarwal, 2003; Gounopoulos, 2006). This study argues that the involvement of institutional investors is an IPO could be interpreted as a signal of quality of the issuing companies. Measuring the institutional investors' involvement using the proportion of IPOs offered to the institutional investors against the total number of shares offered, this study expects a positive relationship between institutional investors' involvement and initial return.

Next is lock-up provision's (lock-up ratio). Lock-up ratio (LOCKUP) is defined as the percentage of shares locked by promoters. Lock-up provision has been implemented on a mandatory basis on major shareholders (i.e., promoters) of IPO issuers in Malaysia since 3 May 1999. In detail, the Malaysian capital market regulator, the Securities Commission (SC) has set a minimum percentage (e.g., 45 per cent of the total shares outstanding) that need to be retained by the promoters for a certain length of time upon the listing of the shares. While there is an argument that the mandatory ruling will cause lock-up provision to be irrelevant to investors because it becomes a norm to all IPOs, this study argues that the case is different in Malaysia. This is because promoters of most IPO issuers in Malaysia voluntarily lock more shares than mandated by the SC. This study observes there are promoters of IPO issue who voluntarily lock-up 84 per cent of their shares despite the 45 per cent requirement. The voluntary act in the practice of the lock-up provision carries an important signal (Arthurs et 


\section{Macrothink Institute ${ }^{\mathrm{TM}}$}

al., 2009; Hakim, Lypny, \& Bharbra, 2012) because it reflects the behaviour of the firms. Based on signalling theory, lock-up ratio could reflect quality of the IPOs (Mohan \& Chen, 2001; Wan-Hussin, 2005). A higher lock-up ratio infers that affected shareholders agree to retain their shareholdings in the firms despite the high initial return in the immediate aftermarket. Hence, the investors will be more confident in the IPO issuer (Arthurs et al., 2009; Georgen et al., 2006; Islam and Munira, 2004). Subsequently, the higher is the lock-up ratio, the higher is the initial return.

The list of control variables, predicted sign and relevant literature supporting employment and prediction on sign of these control variables are summarised in Table 1.

Table 1. Summary of Control Variables and Expected Sign

\begin{tabular}{|c|c|c|c|}
\hline No. & Control Variable & $\begin{array}{l}\text { Exp. Sign. } \\
\text { (RETURN) }\end{array}$ & Past Studies \\
\hline 1. & Demand of IPO (DEMAND) & $+\mathrm{ve}$ & Abdul Rahim et al., 2013, Islam and Munira (2004) \\
\hline 2. & Supply of IPO (SUPPLY) & -ve & $\begin{array}{l}\text { Bayley et al. (2006), Chong et al. (2009), Tran et al. (2007), } \\
\text { Sapian et al. (2012) }\end{array}$ \\
\hline 3. & Stock Market Condition (MKTLOOK) & $+\mathrm{ve}$ & Chong et al. (2009), Ritter and Welch (2002) \\
\hline 4. & Investors Sentiment (HEUREP) & $+\mathrm{ve}$ & Bayley et al. (2006), Chong et al. (2011) \\
\hline 5. & Underwriter Reputation (UNDREP) & $+\mathrm{ve}$ & Fang (2005), Yung \& Zender (2010) \\
\hline 6. & $\begin{array}{l}\text { Institutional Investors' involvement } \\
\text { (INSVOL) }\end{array}$ & $+\mathrm{ve}$ & Aggarwal (2003), Gounopoulos (2006) \\
\hline 7. & Lock-Up Ratio (LURAT) & $+\mathrm{ve}$ & $\begin{array}{l}\text { Islam and Munira (2004), Mohan and Chen (2001), } \\
\text { Wan-Hussin (2005) }\end{array}$ \\
\hline
\end{tabular}

Note: +ve indicates an expectation on the positive relationship while -ve indicates an expectation on the negative relationship.

\section{Estimation Models}

The following multiple regression equations are applied to examine the influence of offer-for-sale on initial return using two measurements;

$$
\begin{aligned}
& \operatorname{RETURN}_{\text {OPEN }}(i)_{i}=\alpha+\beta_{1} \text { OFSALE }_{i}+\beta_{j} \sum_{j=1}^{7} C V_{j}+\varepsilon \\
& \operatorname{RETURN}_{\text {CLOSE }}(i)_{i}=\alpha+\beta_{1} \text { OFSALE }_{i}+\beta_{j} \sum_{j=1}^{7} C V_{j}+\varepsilon
\end{aligned}
$$


where, $\alpha$ is the regression intercept, $\beta$ is the estimated coefficient of the respective predictor variable, $C V_{i, j}$ is the control variables from $j=1, \ldots, 8$ for the ith IPO, while the remaining variables are as defined in earlier section and $\varepsilon$ is the error term.

\section{Empirical Results and Discussion}

\section{Preliminary Results}

Table 2 presents the descriptive statistics of 419 Malaysian IPOs, listed from 2000 to 2015. The average return (opening price) is 0.28 percent from a minimum of -0.68 percent to a maximum of 4.04 percent. While the avarage return (closing price) is 0.29 percent ranging from -0.68 percent to 3.60 percent. For explanatory variables, mean of offer for sale ratio is 0.25 percent which ranges from a minium of nil to a maximum of 1.00 percent.

Table 2. Profile of Sample IPOs, 2000 - 2015

\begin{tabular}{|c|c|c|c|c|c|}
\hline Items & Mean & Median & Min. & Max. & $\begin{array}{l}\text { Std. } \\
\text { Dev. }\end{array}$ \\
\hline Return (Open Price) $(\%)$ & 0.28 & 0.15 & -0.68 & 4.04 & 0.55 \\
\hline Return (Close Price) $(\%)$ & 0.29 & 0.15 & -0.68 & 3.60 & 0.48 \\
\hline Offer for Sale $(\%)$ & 0.25 & 0.00 & 0.00 & 1.00 & 0.31 \\
\hline OSR & 31.00 & 14.72 & -0.89 & 377.95 & 47.54 \\
\hline \multirow[t]{2}{*}{ Offer Size (RM) } & $1.76 \mathrm{E}+0$ & 19560000 & 2400000 & $1.25 \mathrm{E}+10$ & $9.14 \mathrm{E}+$ \\
\hline & 8 & & & & 08 \\
\hline Mean KLCI (\%) & 0.01 & 0.04 & -1.56 & 1.07 & 0.36 \\
\hline HEU. Rep (Investor Sentiment) (\%) & 0.30 & 0.16 & -0.38 & 3.17 & 0.43 \\
\hline Underwriter Mkt Share & 7.80 & 2.70 & 0.00 & 90.80 & 11.78 \\
\hline Inst. Investor Involvement ( $\%)$ & 0.45 & 0.53 & 0.00 & 1.00 & 0.33 \\
\hline Lock-Up Shares $(\%)$ & 0.56 & 0.55 & 0.00 & 0.84 & 0.10 \\
\hline
\end{tabular}

Note: Sample size, $\mathrm{n}=419$ for the period from January 2000 to December 2015. Initial return (RETURN) is measured as the percentage change in price, between the closing price on the first day of trading and the offer price. . $P_{O P E N i}$ is an opening price on the first trading day (see. Eq. 1a), while $P_{C L O i}$ is a closing price on the first trading day (see. Eq. 1b). Both price is used to calculate initial return (RETURN).

Table 3 presents correlations among independent variables which are below 0.90 cut-off point (Aeteriou \& Hall, 2007) for any severe threat of multicollinearity. An exception is the 0.268 correlation between underwriter market share and institutional investor involvement, two parameters of initial return, which indicate the possibility of high correlation between two main independent variables. 
Table 3. Correlation Matrix

\begin{tabular}{|c|c|c|c|c|c|c|c|c|c|c|}
\hline$\underline{\text { Variables }}$ & 1 & 2 & 3 & 4 & 5 & 6 & 7 & 8 & 9 & 10 \\
\hline 1. RETURN RPEN $_{\text {OP }}$ & 1 & 0.804 & -0.201 & 0.315 & -0.192 & 0.90 & 0.211 & 0.063 & 0.025 & -0.140 \\
\hline 2. RETURN $_{C L O S E}$ & & 1 & -0.208 & 0.427 & -0.222 & 0.129 & 0.277 & 0.046 & 0.060 & -0.060 \\
\hline 3. OFSALE & & & 1 & -0.223 & 0.384 & -0.001 & -0.063 & 0.022 & -0.255 & 0.016 \\
\hline 4. DEMAND & & & & 1 & -0.250 & -0.002 & 0.178 & -0.103 & 0.221 & -0.097 \\
\hline 5. SUPPLY & & & & & 1 & -0.031 & -0.032 & 0.243 & -0.274 & 0.054 \\
\hline 6. MKTLOOK & & & & & & 1 & 0.106 & -0.049 & 0.053 & -0.031 \\
\hline 7. HEUREP & & & & & & & 1 & 0.159 & -0.131 & -0.117 \\
\hline 8. UNDREP & & & & & & & & 1 & -0.268 & 0.028 \\
\hline 9. INSVOL & & & & & & & & & 1 & 0.026 \\
\hline 10. LURAT & & & & & & & & & & 1 \\
\hline
\end{tabular}

Notes: Abbreviations RETURN $\mathrm{N}_{O P E N}=$ return using percentage change in opening price on the first day of trading and the offer price; RETURN $N_{C L O S E}=$ return using percentage change in closing price on the first day of trading and the offer price; OFSALE = offer for sale; DEMAND = demanf of IPO; SUPPLY = Supply of IPO; MKTLOOK = Stock Market Condition; HEUREP = Investors Sentiment; UNDREP = Underwriter Reputation; INSVOL = Institutional Investors' Involvement; LURAT = Lock-Up Ratio; and the numbers in column headings correspond with the number of variables in row.

\section{Main Empirical Results}

The main results of this study are presented in Table 4 using two model specifications. Model A reports regression result when the initial return is using percentage change in opening price on the first day trading and the offer price while Model B presents initial return is using percentage change in closing price on the first day trading and the offer price. To begin with, the two models in Table 4 satisfy all OLS assumptions relating to heteroskedaticity (White's general test) and model specification (RAMSEY' test). In regard to autocorrelation, the Durbin-Watson $d$ statistics in Model A and Model B record values of less than 2, indicating the potential existence of autocorrelation. Hence, the Newey-West is employed to correct for the threat of autocorrelation.

Overall, Model A produces an adjusted R-squared of 24.88 percent which is higher than an adjusted R-squared of 15.45 percent in Model B. The two figures indicate that collectively, all explanatory variables tested in this study are able to explain at least the 24.88 percent and 15.45 percent of the variations in IPO initial returns (offer to open price) and IPO initial return (offer to close price), accordingly. The F-statistics verufy the goodness-of-fits of both of the models are satisfactory $(p<0.01)$. In terms of the factors that have significnt coefficient in both models, only lock up shares do not have significant relationship.

Refering to Table 4, a negative coeffficient sign for offer for sale in shown in both Model A and Model B. For demand, also positive coefficient sign is found in both models. The result implies that when there is a high demand on the IPOs, it will influence a positive return of the 
IPOs and it is in line with the prediction. While supply has a negative coefficient sign in both models it indicates that when there are too many supply number of IPOs, it will reduce amount of initial return of the IPOs. Market outlook also have a positive coefficient since when the market condition is stable, the IPO will also perform good since investors prefer to invest on the IPO.

Similarly important is the finding on the positive significant relationship for investment sentiment for both models. This is due to the when majority of the investors have a confidence towards the potential of the IPO, it will create demand which lead to increase in price of the IPO and initial return. Underwriter reputation also proven as one of the factor that may influence the IPO after market performance. When the underwriter has a good reputation in underwritting the prospectus, it might attract a lot of potential investors to invest on the IPO since the prospectus provide good information on the potential of company in the future. However, institutional investors investment have a negative coefficient sign in both models. When the institutional investors invest in a big amount on the IPO, there is a prediction that at any time they might sell the stocks which lead to big impact towards the after market performance especially to the company. Some of the investors might worried when there are big percentage of institutional investors investment on the IPO. Meanwhile, the consistency between results and prediction is also found in both models for lock-up period. The positive coefficient sign suggest that the longer the lock-up period might give a good signal on the IPO after market performance. The longer the period of the lock-up, the longer the time period that the promoters would remain committed to their companies. In that sense, the longer the lock-up period will affect the shareholders' interest continues to be aligned with those of other shareholders. New and unaffected shareholders will be more willing to retain shares rather than to sell their IPOs immediately upon listing. In short,lock-up period will encourages the shareholders to remain in the company for a longer term rather than the signal that reflect the confidence of investors on the company which can help to increase the IPO initial returns. 
Table 4. Regression Resutls on the Influence of Offer for Sales on IPO After Market Performance

\begin{tabular}{|c|c|c|c|c|c|}
\hline & & \multicolumn{2}{|c|}{$\begin{array}{c}\text { MODEL A: OPENING } \\
\text { PRICE }\end{array}$} & \multicolumn{2}{|c|}{$\begin{array}{c}\text { MODEL B: CLOSEING } \\
\text { PRICE }\end{array}$} \\
\hline \multirow[t]{2}{*}{ Variables } & \multirow[t]{2}{*}{$\begin{array}{l}\text { Exp. Sign } \\
\text { (RETURN) }\end{array}$} & \multicolumn{2}{|c|}{$\begin{array}{l}\text { INITIAL RETURN (OFFER TO } \\
\text { OPEN PRICE) }\end{array}$} & \multicolumn{2}{|c|}{$\begin{array}{l}\text { INITIAL RETURN )OFFER } \\
\text { TO CLOSE PRICE) }\end{array}$} \\
\hline & & Coefficient & t-statistics & Coefficient & t-statistics \\
\hline \multicolumn{6}{|l|}{ Main Variable } \\
\hline $\begin{array}{l}\text { RETURN }_{O P E N} \\
\text { RETURN }_{C L O S E} \\
\text { OFSALE }\end{array}$ & & -0.108 & $-1.991 *$ & -0.167 & $-2.586^{*}$ \\
\hline \multicolumn{6}{|l|}{ Control Variables } \\
\hline DEMAND & + & 0.004 & $4.309^{*}$ & -0.280 & $4.704 *$ \\
\hline SUPPLY & - & -0.043 & $-3.340^{*}$ & -0.123 & $-3.124 *$ \\
\hline MKTLOOK & + & 0.151 & $2.580^{*}$ & 0.023 & $1.697^{*}$ \\
\hline HEUREP & + & 0.197 & $2.151^{*}$ & -0.005 & $1.650^{*}$ \\
\hline UNDREP & + & 0.003 & $1.820^{*}$ & -0.030 & $1.808^{*}$ \\
\hline INSVOL & + & -0.006 & $-2.900 *$ & -0.035 & $-3.180 *$ \\
\hline LURAT & + & 0.0017 & 0.100 & 0.011 & -1.183 \\
\hline $\mathrm{R}^{2}$ & & \multicolumn{2}{|c|}{0.2631} & \multicolumn{2}{|c|}{0.1707} \\
\hline Adjusted $\mathrm{R}^{2}$ & & \multicolumn{2}{|c|}{0.2488} & \multicolumn{2}{|c|}{0.1545} \\
\hline F-statistics & & \multicolumn{2}{|c|}{18.303} & \multicolumn{2}{|c|}{10.5477} \\
\hline$p$-value (F-stats) & & \multicolumn{2}{|c|}{0.0000} & \multicolumn{2}{|c|}{0.0000} \\
\hline Durbin-Watson & & \multicolumn{2}{|c|}{1.660} & \multicolumn{2}{|c|}{1.7435} \\
\hline \multicolumn{6}{|l|}{ VIF Range } \\
\hline \multicolumn{6}{|l|}{ Ramsey TEST: } \\
\hline F-Test Statistics & & \multicolumn{2}{|c|}{0.2866} & \multicolumn{2}{|c|}{0.776} \\
\hline$p$-value & & \multicolumn{2}{|c|}{0.5927} & \multicolumn{2}{|c|}{0.378} \\
\hline
\end{tabular}

Notes: Sample size $(\mathrm{N})=419$. Asteriks * indicate significant at $10 \%$.

\section{Conclusion and Discussion}

This study examines the impact of offer for sale on the IPO after market performance. Using a final sample of 419 IPOs listed in Bursa Malaysia for the period from January 2000 to December 2015, this study contributes to the IPO literature by emphasizing on the role of the offer for sale as signalling of the performance of the IPO after market. The finding of this study shows that offer for sale is positively and significantly related to IPO after market performance. Meanwhile, this study finds no significant relationship between lock-up shares although positive sign for lock-up shares on initial return is consistent to the prediction. 


\section{Acknowledgement}

The authors would like to acknowledge that this paper is part of a research project funded by Research Acculturation Grant Scheme (RAGS) awarded by Universiti Teknologi MARA (UiTM) and Ministry of Higher Education, Malaysia and (RAGS/1/2015/SS01/UITM/02/1).

\section{References}

Abdul Rahim, R., Che Embi, N. A., \& Yong, O. (2012). Winner's curse and IPO initial performance. New evidence from Malaysia. International Journal of Business and Management Studies, 4(2), 151-159.

Abdul Rahim, R., Sapian, R. Z. Z., Yong, O., \& Auzairy, N. A. (2013). Flipping activity and subsequent aftermarket trading in Malaysian IPOs. Asian Academy of Management Journal of Accounting and Finance, 9(1), 113-128.

Aggarwal, R. (2003). Allocation of initial public offerings and flipping activity. Journal of Financial Economics, 68(1), 111-135. https://doi.org/10.1016/S0304-405X(02)00250-7

Arthurs, D. J., Busenitz, W. L., Hockisson, E. R., \& Johnson, A. R. (2009). Signaling and initial public offerings: The use and impact of the lockup period. Journal of Business Venturing, 24(4), 360-372. https://doi.org/10.1016/j.jbusvent.2008.02.004

Bayley, L., Lee, P. J., \& Walter, T. S. (2006). IPO Flipping in Australia: Cross-sectional explanations. Pacific-Basin Finance Journal, 14(4), 327-348. https://doi.org/10.1016/j.pacfin.2006.01.002

Bildik, R., \& Yilmaz. M.K., (2008). The Market Performance of Initial Public Offerings in the Istanbul Stock Exchange. Finansal Piyasalar, 2(2), 49-75.

Che Yahya, N., \& Abdul Rahim, R. (2015). Role of Lockup Provision and Institutional Investors $^{\text {ee }}$ Participation in Restricting Flipping Activity. Is There a Moderating Effect of Investor Demand?. Asian Academy of Management Journal of Accounting and Finance, 11(2), 1-29.

Chong, F. N., Ahmad, Z., \& Ali, R. (2011). Representative heuristics and the aftermarket dynamics of the new listings in Malaysia. Labuan Bulletin of International Business and Finance, 9, 1-11.

Chong, F. N., Ali, R., \& Ahmad, Z. (2009). Does noise signal affect flipping activities. International Journal of Banking and Finance, 6(2), 111-127.

Fang, L. H. (2005). Investment bank reputation and the price and quality of underwriting $\begin{array}{llll}\text { services. Journal of } & \text { Finance, }\end{array}$ https://doi.org/10.1111/j.1540-6261.2005.00815.x

Garfinkel. (1993). IPO Underpricing, Insider Selling and Subsequent Equity Offerings:Is Underpricing a Signal of Quality? Financial Management, 22(1), 74-83. 
Georgen, M., Renneboog, L., \& Khurshed, A. (2006). Explaining the diversity in shareholders lockup agreements. Journal of Financial Intermediation, 15(2), 254-280. https://doi.org/10.1016/j.jfi.2005.10.001

Gounopoulos, D. (2006). Activity in fixed offer price mechanism Allocated IPOs. Working Paper. University of Surrey. United Kingdom. 1-24. https://doi.org/10.1016/B978-075067975-6.50014-1

Hakim, T., Lypny, G., \& Bhabra, H. S. (2012). IPO lockup expiration in the Middle East and North Africa. Journal of Multinational Financial Management, 22(5), 252-262. https://doi.org/10.1016/j.mulfin.2012.06.005

Islam, M. S., \& Munira S. (2004). IPO flipping and its determinants in Bangladesh. Dhaka University Journal of Business Studies, 25(1), 1-23.

Kavita W,V., Nagi R, A, Abdulkadir M., (2016) IPO and SEOs, Real Investments, and Market Timing: Emerging Market Evidence. Journal of Intenational Financial Markets, Institutional and Money, 45, 21-41. https://doi.org/10.1016/j.intfin.2016.05.007

Mohan, J. N., \& Chen, R. C. (2001). Information content of lock-up provision in initial public offerings. International Review of Economics and Finance, 10(1), 41-59. https://doi.org/10.1016/S1059-0560(00)00070-8

Mohd Rashid, R., Abdul Rahim, R., \& Che-Yahya, N. (2016). Shareholder Retention Influence on the Flipping Activity of Malaysian IPOs. Pertanika Journal of Social Science and Humanity. 24(S), 133 - 144.

Mohd Rashid, R., Abdul Rahim, R., \& Yong, O. (2014). The influence of lock-up provisions on IPO initial returns: Evidence from an emerging market. Economic Systems, 38, 487-501. https://doi.org/10.1016/j.ecosys.2014.03.003

Philippe. E., (2011). IPO. A Global Guide. Hong Kong University Press.

Ritter, J. R., \& Welch, I. 2002. A review of IPO activity, pricing and allocation. Journal of Finance, 57(4), 1795-1829. https://doi.org/10.1111/1540-6261.00478

Sapian, R. Z. Z., Abdul Rahim, R., \& Yong, O. (2012). Underpricing, flipping activity and aftermarket liquidity of IPOs. Jurnal Pengurusan, 34, 29-43.

Schaub, M., Casey, K., \& Washer, K (2004). Banking Industry IPO Returns: A Test of the Informational Asymmetry Hypothesis. Southwest Business and Economics Journal, 18-24.

Tran, L. H., Kalev, P. S., \& Westerholm, J. (2007). An analysis of the flipping activities in early aftermarket trading. Unpublished Manuscript. University of Sydney. 1-41.

Wan-Hussin, N. W. 2005. The effects of owners' participation and lockup on IPO underpricing in Malaysian. Asian Academy of Management Journal, 10(1), 19-36.

Yong, O. (2010). Initial premium, flipping activity and opening-day price spread of Malaysian IPOs. Capital Markets Review, 18(1), 45-61. 
Yung, C., \& Zender, F. J. (2010). Moral hazard, information asymmetry and IPO lockups. Journal of Corporate Finance, 16(3), 320-332. https://doi.org/10.1016/j.jcorpfin.2009.12.004 